(c) 2018 International Journal of Nursing and Midwifery Science (IJNMS)

This is an Open Access article distributed under the terms of the Creative CommonsAttribution 4.0 International License which permits unrestricted noncommercial use, distribution, and reproduction in any medium, provided the original work is properly cited.

\title{
LEVEL OF TURMERIC ACID THERAPY EFFECTIVENESS TO REDUCE
} INTENSITY OF MENSTRUAL PAIN

\author{
Sri Mukhodim Faridah Hanum ${ }^{1}$, LidaKhalimatus Sa'diya ${ }^{2}$ \\ UMSIDA RamePilang street No 4 Sidoarjo regency, School of health Bina Sehat PPNI Jabon \\ street KM 6 Mojoanyar Mojokerto regency
}

Email correspondence: Lidarafi2@gmail.com

\section{ABSTRACT}

Keywords

Menstrual pain is an incidence of discomfort during menstruation. The current incidence of menstrual pain in the world is very high. According to epidemiological studies, the incidence rate in the United States is estimated at $45-90 \%$, while a menstrual pain in Indonesia is $64.25 \%$ of total women who have menstrual (Proverawati, 2012). It is necessary to handle both pharmacological and non-pharmacological therapies. Test the research to analyze the effectiveness level of non-pharmacology therapy (turmeric acid and green coconut water) for decreasing intensity of menstrual pain in adolescent at Faculty of Health Sciences Muhammadiyah University of Sidoarjo. The method of this research is experimental with the quantitative approach of pre and post-test of Wilcoxon.Summer sample 40 respondents. Data collection using questionnaires. The results of research using turmeric acid and green coconut water in pre and post-treatment there were significant changes after the 3rd-day treatments with $P=0,000(p<0,05)$. To see the effectiveness of treatment with descriptive to know the mean value, got the result using turmeric acid with mean value 0,45 whereas green coconut water means value 0,60 with difference 0,15 point higher in green coconut water. Nodes in this study are the level of effectiveness of decreasing the intensity of menstrual pain better by consuming green coconut water than the use of turmeric acid,.suggested to increase understanding of the community will be important to use non-pharmacology therapy in overcoming menstrual pain. 


\section{PREFACE}

Menstrual pain is an incidence of discomfort during menstruation, usually with pain and centered on the lower abdomen. Menstrual pain complaints may occur ranging from mild to severe pain. Menstrual pain can be divided into two, namely primary menstrual pain and secondary menstrual pain (Sarwono, 2011). The current rate of menstrual pain in the world is very high. According to epidemiological studies, the incidence of menses in the United States is estimated to be as much as $45-90 \%$, while the incidence of menstrual pain in Indonesia is $64.25 \%$ divided into two groups of $54.89 \%$ primary menstrual pain, and 9.36 is secondary pain menstruation (Proverawati, 2012).

The results of the study by Sharma, et al (2008) of the number of adolescent respondents who are still in school, as many as $35 \%$ usually said teenagers do not follow the lessons at school during menstrual pain and 5\% said coming to school but who only do sleep in the classroom.

Several nonpharmacy approaches in reducing menstrual pain have been emerging. One of them is by homeopathic methods (e.g, belladonna and chamomilla), biofeedback, acupuncture, relaxation techniques, massage, youthful water consumption, aromatherapy (e.g, rose oils), and the use of certain herbal remedies (Varney, 2007).

Some herbal ingredients that can be used as a remover of menstrual pain contain many Simplicia which are useful as anti-pain, anti-inflammation and Antispasmodinamic (anti-seizure muscle) such as Consumption of green coconut water, sour turmeric, tea, milk chocolate (Suharmiati, 2011).

Turmeric acid is also used as a traditional herb that contains anti-pain that works to suppress prostaglandin synthesis so that it can overcome the pain during menstruation. Consume turmeric acid is analgesia, antipyretic, inflames, antipyretic and as a reduction of psychic pressure so that will reduce or inhibit uterine contractions. For women who experience pain during menstruation try a turmeric acid herb that is efficacious to alleviate and overcome the pain of menstruation (Pramono, 2009).

Consumption of green coconut water to be effective to reduce menstrual pain by way of drinking two times a day $1 \mathrm{cup}(250 \mathrm{ccs})$ consecutively for three days (Sumino, 2014).

\section{METHOD}

This research is a experimental research with a qualitative approach. The subjects of the study were students at the Faculty of Health Sciences of Muhammadiyah University of Sidoarjo who experienced menstrual pain and were willing to thoroughly amount to 40 female students, divided into 2 groups, Group 1 amounted to 20 groups in the treatment of acid turmeric consumption during menstruation day 1-3 doses needed 25 grams of turmeric acid powder brewed with $150 \mathrm{cc}$ water taken with a dose of 1 time a day and group 2 amounted to 20 people were given the treatment of green coconut water consumption during menstruation day $1-3$ consecutively, the dose is 1 cup ( $250 \mathrm{ccs}) 2$ times per day in drinking morning and afternoon.

Data retrieval uses questionnaires in 2 menstrual cycle that is on December 12 , 2017, until January 28, 2018. Variable in this research is turmeric acid to menstrual pain. And the second variable consumption of green coconut water consumption against menstrual pain. The result of the research was conducted by using bivariant test with Wilcoxon to analyze the results of posttreatment and post-treatment, to know the effectivity level between turmeric acid and coconut water using descriptive statistic test to know the mean value.

\section{RESULT}

a. Frequency Distribution Consumption of sour turmeric 
1. Menstrual pain rate pretreatment

\begin{tabular}{lll}
\hline Pain Rate & $\mathrm{N}$ & Percentage (\%) \\
\hline Light & 6 & 30 \\
\hline Medium & 13 & 65 \\
\hline Weight & 1 & 5 \\
\hline Total & 20 & 100 \\
\hline
\end{tabular}

The data above shows $65 \%$ of respondents feel moderate pain and 5\% feel pain.

2. Menace pain level post-treatment hair to 3

\begin{tabular}{lll}
\hline Pain Rate & $\mathrm{N}$ & Percentage (\%) \\
\hline No pain & 16 & 80 \\
\hline Light & 3 & 15 \\
\hline Medium & 1 & 5 \\
\hline Total & 20 & 100 \\
\hline $\mathrm{P}=0,000$ & & \\
\hline
\end{tabular}

The data above show that $80 \%$ of respondents do not have menstrual pain, $15 \%$ mild pain and 5\% moderate pain. There was a significant change in pre and posttreatment on day 3 with $\mathrm{P}=0,000$ ( $\mathrm{P}$ $<0,05)$.

b. Frequency Distribution of Green Coconut Water Consumption

1. Pain level of menstruation pretreatment

\begin{tabular}{lll}
\hline Pain Rate & $\mathrm{N}$ & Percentage $(\%)$ \\
\hline Light & 6 & 30 \\
\hline Medium & 13 & 65 \\
\hline Very heavy & 1 & 5 \\
\hline Total & 20 & 100 \\
\hline
\end{tabular}

The data above shows $65 \%$ of respondents feel moderate pain and 5\% feel the pain is heavy.
2. Menstrual pain rate post-treatment day 3

\begin{tabular}{lll}
\hline Pain Rate & $\mathrm{N}$ & Percentage (\%) \\
\hline No pain & 11 & 55 \\
\hline Light & 8 & 40 \\
\hline Medium & 1 & 5 \\
\hline Total & 20 & 100 \\
\hline $\mathrm{P}=0,000$ & & \\
\hline
\end{tabular}

The data above show that $55 \%$ of respondents did not have menstrual pain, $40 \%$ mild pain and 5\% moderate pain. There was a significant change in pre and posttreatment on day 3 with $\mathrm{P}=0,000$ ( $\mathrm{P}$ $<0,05)$.

c. The effectiveness of Non-Pharmacology Therapy to Reduce Intensity of Menstrual Pain.

From the data analysis using Wilcoxon test, it is found that $P$ value 0,0 where $(P<0,05)$ this proves there is the difference of pain scale of menstrual pain before using treatment and after using treatment. To see the effectiveness of treatment that has been used then the use of statistical tests descriptive to obtain the mean value in both treatments, obtained results using turmeric acid with a mean value of 0.45 whereas using turmeric mean value of 0.60 with the difference of 0.15 points higher in coconut water.

\section{DISCUSSION}

\section{Description of the effectiveness of turmeric acid on the incidence of menstrual pain in the Faculty of Health, Muhammadiyah University of Sidoarjo}

From the results of the data above shows a significant change after treatment day 3dapat reduce the intensity of menstrual pain. In some studies have big that turmeric acid can help treat some diseases such as inflammation or pain caused by menstruation. This turmeric acid 
is a powerful antioxidant to prevent the destruction of cell membranes, the destruction of DNA due to young stimulation occurs in cells, but turmeric acid can reduce inflammation caused by menstruation (Suharmiati, 2011).

Consume boiled turmeric acid can reduce the intensity of painful menstrual pain. The acid turmeric decoction has an antioxidant activity and because it contains phenolic compounds. Turmeric acid has a content such as a curcuminoid, essential oils, flavonoids, and others use as the analgesic (pain relievers), anti-inflammatory and so on, so the pain felt during menstruation can be reduced by consuming acidic turmeric stew on a regular basis. Thus this study can be concluded that the provision of sour turmeric drink can reduce the intensity of menstrual pain (Hadirman, 2014).

1.1 Overview of the effectiveness of green coconut water on the incidence of menstrual pain in the Faculty of Health, Muhammadiyah University of Sidoarjo

From the results of the data above shows a significant change after the treatment of day 3 can reduce the intensity of menstrual pain. During the study of respondents at the time of menstruation do the consumption of green coconut water 2 times a day with a dose of $250 \mathrm{ml}$ once drinking during menstruation day for 3 (three) days. The results of this study are in line with research from Lestari (2015) in Yogyakarta which says that green coconut water treatment can decrease in women who experience menstrual pain, this is because green coconut water has many high nutrient contents for various health.

This is in accordance with the theory of Meilaty (2011) which states that coconut water contains electrolytes and minerals. The fluid and blood that come out can be replaced by electrolytes and folic acid contained in green coconut water.

Electrolytes are used to prevent dehydration. in the process of producing red blood cells the role of folic acid. Menstrual pain is caused by an imbalance in prostaglandin levels. hypercontractility The uterus caused by prostaglandins causes painful complaints during menstruation.

Green coconut water contains vitamins and minerals that stimulate progesterone production in stable amounts. Adequate progesterone levels will facilitate the process of decay of the endometrium and the pain that arises will soon pass.

Coconut water can be utilized to cope with various health problems, so great benefits of coconut water because coconut water contains many substances that are important for maintaining a healthy body. Coconut water has long been known as a source of growth substance that is cytokinin, the average caloric value found in coconut water is about 17 calories per 100 gram. Green coconut water, compared with other types of coconut contains many of the highest antitoxin (Anonymous, 2010).

Based on the results of this study can be concluded that the consumption of menstrual pain at the beginning of menstruation can reduce the intensity of pain during menstruation.

\subsection{Level Effectiveness of Turmeric Acid and Green Coconut Water To Reduce Intensity of Menstrual Pain In Health Faculty of Muhammadiyah University of Sidoarjo}

To maintain the effectiveness of treatment using descriptive statistical test by knowing mean, the results obtained using turmeric mean value of 0.45 whereas using green coconut water mean value 0.60 , then the green coconut water yield higher than turmeric acid means the level of effectiveness consumption of green coconut water is better in comparison with the use of turmeric acid. Changes in treatment result from day 1 to day 3 on the consumption of green coconut water faster reduce the intensity of menstrual pain compared to the use of turmeric acid. On the first day, the consumption of green coconut water is still more significant to reduce the intensity of menstrual pain than the sour acids. 


\section{CONCLUSION}

The use of turmeric acid and green coconut water with the appropriate dose can effectively reduce the intensity of menstrual pain, while the comparison of the effectiveness level of the 2 ways is better on the respondents who consume green coconut water than turmeric acid.

It is suggested to increase public understanding about the importance of nonpharmacology therapy in overcoming menstrual pain.

\section{REFERENCE}

Anonim2. 2010. Kandungan Buah Kelapa Dilihat dari Segi Kesehatan. Diaksesdarihttp://smallcrab.com/kese hatan/643-kandungan-buah-kelapadilihat dari segi-kesehatan pada 17 Februari 2017

Hadirman, I. 2014. Sehat Alami dengan Herbal. Jakarta: PT. Gramedia utama.

Meilaty, Ika. 2011. Intervensi Pemberian Air Kelapa Segar dan Olahan pada Wanita Remaja Penderita Keluhan Menstruasi. Diakses darihttp://ikameilatywordpress.com/2 011/05/06/pada 17 Februari 2017

Ministudino, G. 2013. Minuman Tradisional Indonesia. Jakarta: Agro Media Pustaka.

Proverawati, A, \& Misaroh, S.2009. Menarche Menstruasi Pertama Penuh Makna. Yogyakarta: Nuha Medika.

Suharmiati,2011.Ramuan Tradisional untuk Keadaan Darurat di Rumah.Jakarta: Agro Media Pustaka.

Sumino, Nursanti, F.A., Trisnawati, D. 2012. Studi Analisa Pemanfaatan Air Kelapa sebagai Intervensi Non Farmakologi dalam Mengurangi Nyeri Haid pada Remaja dalam Sudut Pandang Keperawatan, dalam http://jurna;.stikeskusumahusada.ac.i
d/index.php/JK/article/download/28/ 81. Diakses tanggal 18 Maret 2017.

Lestari. 2011. Pengaruh Air Kelapa Hijau terhadap Tingkat Nyeri Haid pada Mahasiswa Prodi Keperawatan STIKES Aisyiyah Yogyakarta.

Verney, H. 2007. Buku Ajar Asuhan Kebidanan edisi Keempat Volume I. Jakarta: EGC. 